\title{
DESAFIOS DA GESTÃO ESCOLAR AGRAVADOS EM TEMPOS DE PANDEMIA
}

\section{CHALLENGES IN SCHOOL MANAGEMENT AGGRAVATED IN TIMES OF PANDEMIC}

\author{
Luis Gustavo Rabello ${ }^{1}$, Mariana Aranha de Souza ${ }^{2 *}$, Igor da Silva Becati ${ }^{3}$, Celso A. Santos Gomes ${ }^{4}$ \\ ${ }^{1}$ Mestrando em Gestão e Desenvolvimento Regional, Centro Universitário do Sul de Minas, Varginha-MG, Brasil, \\ luis.rabello@alunos.unis.edu.br \\ 2 Doutora em Educação, Professora do Mestrado em Gestão e Desenvolvimento Regional do Centro Universitário do Sul de Minas, \\ Varginha-MG, Brasil e Professora do Mestrado em Educação da Universidade de Taubaté, Taubaté-SP, Brasil, \\ profa.maaranha@gmail.com* \\ ${ }^{3}$ Mestrando em Gestão e Desenvolvimento Regional, Centro Universitário do Sul de Minas, Varginha-MG, Brasil, \\ igor.becati@alunos.unis.edu.br \\ ${ }^{4}$ Doutor em Educação, Professor do Mestrado em Gestão e Desenvolvimento Regional do Centro Universitário do Sul de Minas, \\ Varginha-MG, Brasil, celso.gomes@unis.edu.br \\ ${ }^{*}$ Autor de correspondência
}

\section{Resumo}

Os desafios da gestão escolar no contexto da pandemia do Covid-19 e seus impactos no cotidiano das atividades de gestão foram investigados. Participaram da pesquisa seis Gestores Escolares de Instituições de Ensino Privadas de Educação Básica do município de Varginha-MG. Os participantes responderam a um questionário online com o objetivo de identificar o perfil sociodemográfico dos gestores, as concepções de gestão escolar e a atuação em tempos de pandemia. A técnica da Análise de Conteúdo demonstrou que os gestores são experientes na profissão e possuem formação acadêmica e continuada compatível com a função que exercem. Em relação à concepção de Gestão, reconhecem a importância de se exercer uma Gestão Democrática, embora mencionem que algumas decisões competem, exclusivamente, ao Gestor Escolar. Diante do cenário ocasionado pela pandemia da Covid-19, os participantes perceberam desafios e oportunidades. Os desafios estão relacionados às dificuldades de Gestão Financeira e Administrativa e as oportunidades em fortalecer a Gestão Pedagógica e de Pessoas, por meio da inclusão tecnológica e do desenvolvimento de uma comunidade de aprendizagem, permeada pela empatia entre escola e família.

Palavras-chave: Gestão Escolar. Pandemia do Covid-19. Desafios.

\begin{abstract}
The challenges of school management in the context of the Covid-19 pandemic and its impacts on the daily management activities were investigated. Six School Managers of Private Teaching Institutions of Basic Education in the city of Varginha-MG participated in the research. Participants answered an online questionnaire in order to identify the sociodemographic profile of managers, school management concepts and actions in times of pandemic. The Content Analysis technique demonstrated that managers are experienced in the profession and have academic and continuing education compatible with the function they perform. Regarding the concept of Management, they recognize the importance of exercising a Democratic Management, although they mention that some decisions are exclusively the responsibility of the School Manager. Faced with the scenario caused by the Covid-19 pandemic, participants perceived challenges and opportunities. The challenges are related to the difficulties of Financial and Administrative Management and the opportunities to strengthen Pedagogical and People Management, through technological inclusion and the development of a learning community, permeated by the empathy between school and family.
\end{abstract}

Keywords: School Management. Covid-19 pandemic. Challenges.

(C)UNIS-MG. All rights reserved. 


\section{INTRODUÇÃO}

O presente artigo tem por objetivo investigar os impactos e desafios da gestão escolar em escolas privadas do município de Varginha-MG agravados pelos tempos de pandemia. Tal abordagem se deve à descoberta do Covid-19 (ou o novo Coronavírus, como é popularmente conhecido). A Organização Mundial de Saúde (OMS) alertou o mundo todo, em janeiro de 2020, acerca da gravidade da contaminação viral. Em fevereiro do mesmo ano o vírus chegou no Brasil e, logo em 11 de março, foi declarada a pandemia do Covid-19, se caracterizando como uma combinação de crises - social, econômica e sanitária - sem precedentes ao longo da história. Afetando várias esferas, com a educação não foi diferente. O âmbito da gestão escolar foi gravemente afetado, com fechamento de escolas, saída de alunos, cancelamento de matrículas, reconfiguração dos modelos de aula, entre outros.

Lück (2009; 2013) considera que a gestão escolar se define como uma área de atuação profissional na educação, incumbida do planejamento, da organização, da liderança, da orientação, da mediação, da coordenação, do monitoramento e da avaliação de processos essenciais às ações educacionais destinadas à promoção da aprendizagem e da formação dos educandos. Para a autora, a gestão escolar possui dimensões (pedagógica, administrativa, de cultura e clima escolar, de pessoas e de resultados) que precisam ser compreendidas em suas especificidades e em suas possibilidades de integração.

Para a autora, tais dimensões referem-se às áreas que objetivam a preparação, a ordenação, a provisão de recursos e a sistematização do trabalho da gestão a ser desenvolvido. Têm por objetivo a garantia de uma estrutura básica de funcionamento da escola e do próprio processo educativo. Quando sincronizadas e em funcionamento sistêmico, tornam a gestão escolar mais efetiva e, assim, a escola mais produtiva e a educação de mais qualidade.

Para Lück (2009), a dimensão pedagógica destina-se à promoção da aprendizagem e da formação dos educandos. É enaltecida como uma dimensão para a qual todas as demais se convergem, haja vista que se refere à atividade-fim da educação, sendo condição para o desenvolvimento de competências sociais e pessoais. A autora afirma que a dimensão administrativa abrange os processos eficientes e eficazes da gestão de apoio ao funcionamento da dimensão pedagógica, empregando recursos físicos, financeiros, processuais, legais e pessoais para o funcionamento da educação (LÜCK, 2009).

A dimensão cultura e clima organizacional (ou dimensão cultura organizacional) ocupa-se da coletividade da educação, orientada a partir de experiências, valores, condições e demais fatores sociais e institucionais que possam influenciar a promoção da educação. A cultura e o clima organizacional de uma escola se formam a partir de sua história e de sua história com a comunidade/sociedade e com o sistema de ensino de qual faz parte (LÜCK, 2009).

A dimensão de pessoas pode ser relacionada ao bojo do trabalho da gestão escolar, superando a administração de recursos humanos. Para Lück (2009), é a dimensão que mobiliza habilidades e competências para a promoção da aprendizagem e da formação dos educandos.

Ainda para Lück (2009), dimensão resultados compreende processos e práticas da gestão que visam a melhoria dos resultados de desempenho e de avaliações realizadas na escola. Nesta dimensão estão contidos, também, os elementos relacionados ao rendimento, frequência e proficiência dos educandos. 
Lück (2009) ainda afirma que estas dimensões, necessárias para se exercer um papel de gestão democrática e participativa, são construídas a partir de um processo formativo.

Nesse sentido, investigar a gestão escolar em tempos de pandemia se constitui em um fator de extrema relevância para a atualidade, por conta do ineditismo da situação, além de entender os fatores que configuraram erros, acertos, entre outros, para que em cenários semelhantes haja assertivas pautadas em estudos dessa natureza, de entender como pensaram os gestores escolares nas tomadas de decisão para culminar na prática profissional, com os desafios impostos pela pandemia.

\section{REVISÃO DE LITERATURA}

Para o presente artigo, realizou-se uma investigação sobre o panorama de pesquisas existentes sobre a Gestão Escolar em tempos de pandemia. Essa investigação teve por objetivo o mapeamento e a identificação das produções acadêmicas que, nos últimos anos, têm tratado sobre este tema. Como bem recomendam Marconi e Lakatos (2017), o primeiro requisito para produção científico-acadêmica de algo novo, visando aprimoramento do assunto e contribuições com a produção de conhecimentos, tem como subsídio análises realizadas em trabalhos e dados previamente publicados. Este requisito é conhecido como estado da arte ou estado do conhecimento, pois ocupa-se de referenciar o estado atual acerca de determinado tema em estudo.

Inicialmente, a pesquisa procedeu junto à Biblioteca Digital Brasileira de Teses e Dissertações (BDTD), utilizando-se os seguintes descritores combinados: gestão escolar; gestor escolar; escola privada; pandemia; Covid-19; impactos; dificuldades. Contudo, considerando a contemporaneidade do tema, bem como o advento recente da crise sanitária, não foram encontradas dissertações e teses publicadas nos anos de 2020 e 2021.

Frente às dificuldades iniciais, prosseguiu-se a busca sobre pesquisas que envolvessem a gestão escolar em tempos pandêmicos em artigos científicos, trabalhos publicados em congressos (anais), periódicos, revistas especializadas e obra organizada, considerando as bases de dados presentes no Portal de Periódicos da CAPES, por meio da Comunidade Acadêmica Federada (CAFe). Os mesmos descritores combinados foram utilizados.

Foram considerados como critérios de inclusão: publicações em língua portuguesa; publicações dos anos de 2020 e 2021 (considerando o advento pandêmico); publicações cujos objetivos se assemelhassem aos objetivos do presente estudo; e publicações cujo título evidenciasse desafios, impactos e dificuldades da gestão escolar.

Em primeira análise, constatou-se uma dificuldade em achados que contemplassem os mesmos objetivos e título de pesquisa deste estudo - ou seja, com o objetivo de investigar as dificuldades e impactos da gestão de escolas privadas em tempos pandêmicos. Entretanto, foram observadas publicações, cujas temáticas tratavam da gestão escolar e o advento da pandemia.

Após a leitura dos títulos e resumos, foram escolhidos, ao todo, 22 trabalhos que possuem aderência ao tema da pesquisa, devidamente observados no Quadro 1, a seguir. 
Quadro 1 - Trabalhos selecionados para a pesquisa

\begin{tabular}{|c|c|c|c|}
\hline$\#$ & Autor (es) & Título & Local/Ano \\
\hline 1 & $\begin{array}{l}\text { ALVES, S. M. C.; } \\
\text { BARBOSA, M. R. B. }\end{array}$ & $\begin{array}{l}\text { Gestão escolar democrática: dimensão } \\
\text { diretiva aos processos educacionais } \\
\text { significativos. }\end{array}$ & $\begin{array}{l}\text { Research, Society and Development, } \\
\text { v. 9, n. 4, p.1-16, } 2020 .\end{array}$ \\
\hline 2 & ARRUDA, E. P. & $\begin{array}{l}\text { Educação remota emergencial: elementos } \\
\text { para políticas públicas na educação } \\
\text { brasileira em tempos de Covid-19. }\end{array}$ & $\begin{array}{l}\text { EmRede - Revista de Educação a } \\
\text { Distância, v. 7, n. 1, p. 257-275, } 15 \\
\text { maio } 2020 .\end{array}$ \\
\hline 3 & $\begin{array}{l}\text { BALDIN, A. M. A.; } \\
\text { PEDERSETTU, S.; SILVA, } \\
\text { M. B. }\end{array}$ & $\begin{array}{l}\text { Educação básica em tempos de pandemia: } \\
\text { tentativas para minimizar o impacto do } \\
\text { distanciamento e manter o vínculo entre } \\
\text { os alunos, as famílias e a escola. }\end{array}$ & $\begin{array}{l}\text { In: PALÚ, J.; SHUTZ, J. A.; MAYER, L. } \\
\text { (orgs.). Desafios da educação em } \\
\text { tempos de pandemia. Cruz Alta: } \\
\text { llustração, } 2020 .\end{array}$ \\
\hline 4 & $\begin{array}{l}\text { COUTO, E. S.; COUTO, E. } \\
\text { S.; CRUZ, I. de M. P. }\end{array}$ & $\begin{array}{l}\text { \#Fiqueemcasa: Educação na pandemia da } \\
\text { Covid-19. }\end{array}$ & $\begin{array}{l}\text { Revista Educação e Interfaces } \\
\text { Científicas, v. 8, n. 3, p. 200-217, } \\
2020 .\end{array}$ \\
\hline 5 & FIRMINO, M. A. R. & $\begin{array}{l}\text { Os desafios do gestor escolar em tempos } \\
\text { de aprendizagem remota. }\end{array}$ & $\begin{array}{l}\text { Pedagogia em Ação, Belo Horizonte, } \\
\text { v. 13, n. 1, p.275-278, } 2020 .\end{array}$ \\
\hline 6 & $\begin{array}{l}\text { FRANCO, L. R.; FRANCO, } \\
\text { L. S. }\end{array}$ & $\begin{array}{l}\text { Educação Especial: reflexões sobre } \\
\text { inclusão do estudante com deficiência em } \\
\text { tempos de pandemia. }\end{array}$ & $\begin{array}{l}\text { In: PALÚ, J.; SHUTZ, J. A.; MAYER, L. } \\
\text { (orgs.). Desafios da educação em } \\
\text { tempos de pandemia. Cruz Alta: } \\
\text { llustração, } 2020 .\end{array}$ \\
\hline 7 & GIORDANO, D. X. F. & $\begin{array}{l}\text { Um olhar sobre o trabalho dos gestores } \\
\text { escolares no contexto da pandemia. }\end{array}$ & $\begin{array}{l}\text { Educação Básica Online, v.1, n.1, p. } \\
\text { 125-133, jan. } 2021 .\end{array}$ \\
\hline 8 & KIRCHNER, E. A. & $\begin{array}{l}\text { Vivenciando os desafios da educação em } \\
\text { tempos de pandemia. }\end{array}$ & $\begin{array}{l}\text { In: PALÚ, J.; SHUTZ, J. A.; MAYER, L. } \\
\text { (orgs.). Desafios da educação em } \\
\text { tempos de pandemia. Cruz Alta: } \\
\text { llustração, } 2020 .\end{array}$ \\
\hline 9 & $\begin{array}{l}\text { OLIVEIRA, V. C.; NEVES, } \\
\text { O. L; MARTINS, R. N.; } \\
\text { SANTOS, I. }\end{array}$ & $\begin{array}{l}\text { De repente 4.0: mudanças de paradigma } \\
\text { educacional em tempo de pandemia. }\end{array}$ & $\begin{array}{l}\text { In: PALÚ, J.; SHUTZ, J. A.; MAYER, L. } \\
\text { (orgs.). Desafios da educação em } \\
\text { tempos de pandemia. Cruz Alta: } \\
\text { llustração, } 2020 .\end{array}$ \\
\hline 10 & PERES, M. R. & $\begin{array}{l}\text { Novos desafios da gestão escolar e de sala } \\
\text { de aula em tempos de pandemia. }\end{array}$ & $\begin{array}{l}\text { Revista Administração Educacional } \\
\text { da UFPE, Recife-PE, v.11 n. } 1 \text { p. } 20- \\
\text { 31, jan./jun. } 2020 .\end{array}$ \\
\hline 11 & PRALON, E. & $\begin{array}{l}\text { A pandemia com reflexo no clima das } \\
\text { instituições educacionais: instabilidade e o } \\
\text { acentuado índice de incivilidades nas } \\
\text { relações. }\end{array}$ & $\begin{array}{l}\text { Cadernos de Educação: Reflexões e } \\
\text { Debates, v. 19, n. 38, p. 5-17, } 2020 .\end{array}$ \\
\hline 12 & $\begin{array}{l}\text { RIBEIRO, G. S.; ANDRADE } \\
\text { JOSÉ, M. C. }\end{array}$ & $\begin{array}{l}\text { Gestão escolar e a Covid-19: dinâmicas de } \\
\text { trabalho e desafios profissionais durante a } \\
\text { pandemia de } 2020 \text {. }\end{array}$ & $\begin{array}{l}\text { In: SILVA, A. J. N.; BOMFIM, A. L. } \\
\text { (orgs.). Militância política e teórico- } \\
\text { científica da educação no Brasil. } \\
\text { Ponta Grossa/PR: Atena, } 2020 . \\
\end{array}$ \\
\hline 13 & $\begin{array}{l}\text { SILVA, L. A.; PETRY, Z. J. } \\
\text { R.; UGGIONI, N. }\end{array}$ & $\begin{array}{l}\text { Desafios da educação em tempos de } \\
\text { pandemia: como conectar professores } \\
\text { desconectados, relato da prática do } \\
\text { estado de Santa Catarina. }\end{array}$ & $\begin{array}{l}\text { In: PALÚ, J.; SHUTZ, J. A.; MAYER, L. } \\
\text { (orgs.). Desafios da educação em } \\
\text { tempos de pandemia. Cruz Alta: } \\
\text { llustração, } 2020 .\end{array}$ \\
\hline 14 & $\begin{array}{l}\text { SILVA, J. A. D.; } \\
\text { WEINMAN, C. }\end{array}$ & $\begin{array}{l}\text { Os desafios de uma gestão democrática } \\
\text { em tempos de pandemia na escola } \\
\text { pública. }\end{array}$ & $\begin{array}{l}\text { In: PALÚ, J.; SHUTZ, J. A.; MAYER, L. } \\
\text { (orgs.). Desafios da educação em } \\
\text { tempos de pandemia. Cruz Alta: } \\
\text { llustração, } 2020 .\end{array}$ \\
\hline 15 & $\begin{array}{l}\text { VALLE, P. D.; MARCOM, } \\
\text { J. L. R. }\end{array}$ & $\begin{array}{l}\text { Desafios da prática pedagógica e as } \\
\text { competências para ensinar em tempos de } \\
\text { pandemia. }\end{array}$ & $\begin{array}{l}\text { In: PALÚ, J.; SHUTZ, J. A.; MAYER, L. } \\
\text { (orgs.). Desafios da educação em } \\
\text { tempos de pandemia. Cruz Alta: } \\
\text { llustração, } 2020 .\end{array}$ \\
\hline
\end{tabular}




\begin{tabular}{|c|c|c|c|}
\hline 16 & $\begin{array}{l}\text { ANDRADE, G. P. S. B.; } \\
\text { BARBOSA, L. A.; } \\
\text { CARDOSO, M. S.; } \\
\text { OLIVIERA, R. M. S. R. }\end{array}$ & $\begin{array}{l}\text { Desafios para a construção de práticas } \\
\text { docentes em tempo de pandemia. }\end{array}$ & $\begin{array}{l}\text { Research, Society and Development, } \\
\text { v. } 10, \text { n. } 1, \text { p.1-11, } 2021 .\end{array}$ \\
\hline 17 & $\begin{array}{l}\text { BORGES, K. R.; } \\
\text { FIGUEIREDO, S. T.; } \\
\text { AVELINO, W. F. }\end{array}$ & $\begin{array}{l}\text { Gestores pedagógicos em escolas de } \\
\text { ensino integral no estado de São Paulo } \\
\text { durante a Pandemia da Covid-19. }\end{array}$ & $\begin{array}{l}\text { Boletim de Conjuntura (BOCA), Boa } \\
\text { Vista, v. } 5 \text {, n. } 13, \text { p. } 69-76,2021 .\end{array}$ \\
\hline 19 & $\begin{array}{l}\text { FERRAZ, J. P. V.; ABREU, } \\
\text { D. C. DE; MOTTA, M. A. }\end{array}$ & $\begin{array}{l}\text { Regulação do trabalho pedagógico e } \\
\text { escolar em tempo de pandemia. }\end{array}$ & $\begin{array}{l}\text { Notandum, n. 56, p. 111-121, } 24 \text { fev. } \\
2021 .\end{array}$ \\
\hline 20 & $\begin{array}{l}\text { GABRIEL, N. S.; MARÇAL, } \\
\text { G. A.; IMBERNON, R. A. } \\
\text { L.; PIOKER-HARA, F. C. }\end{array}$ & $\begin{array}{l}\text { O retorno às aulas no pós-pandemia: } \\
\text { estudo de caso e análise comparativa } \\
\text { entre o ensino público e o ensino privado. }\end{array}$ & $\begin{array}{l}\text { Terra e Didática, Campinas/SP, v. 17, } \\
\text { n.1, p.1-13,2021. }\end{array}$ \\
\hline 21 & REIS, J. S.; LEAL, D. A. & $\begin{array}{l}\text { A importância da democratização digital e } \\
\text { seus reflexos na educação mediante a } \\
\text { pandemia do COVID-19. }\end{array}$ & $\begin{array}{l}\text { Brazilian Journal of Development, } \\
\text { Curitiba, v.7, n.1, p.10371-10380, } \\
\text { jan. 2021. }\end{array}$ \\
\hline 22 & $\begin{array}{l}\text { SILVA, G.; SILVA, A. V.; } \\
\text { GOMES, E. P. S. }\end{array}$ & $\begin{array}{l}\text { A gestão escolar em tempos de pandemia } \\
\text { na capital alagoana. }\end{array}$ & $\begin{array}{l}\text { Jornal de Políticas Educacionais, v. } \\
\text { 15, n. 1, jan. } 2021 .\end{array}$ \\
\hline
\end{tabular}

Fonte: Dados de pesquisa (2021).

Ao analisar os trabalhos apresentados no Quadro 1, verificou-se que somente quatro deles enunciaram em seus títulos uma combinação de descritores que contemplam dificuldades e impactos da gestão de escolas em tempos pandêmicos. São eles: "A gestão escolar em tempos de pandemia na capital alagoana" (SILVA; SILVA; GOMES, 2021); "Os desafios de uma gestão democrática em tempos de pandemia na escola pública" (SILVA; WEINMAN, 2020); "Novos desafios da gestão escolar e de sala de aula em tempos de pandemia" (PERES, 2020) e "Os desafios do gestor escolar em tempos de aprendizagem remota" (FIRMINO, 2020). Muito embora esses textos tratem do contexto da gestão escolar em tempos de pandemia, em nenhum deles foi anunciado o segmento privado, embora fora contemplado no contexto.

Após a leitura aprofundada dos vinte e dois artigos, pode-se observar que os textos separados contemplam ou abarcam algumas dificuldades enfrentadas pela gestão escolar ou impactos providos nas escolas em tempos pandêmicos. Alguns deles encontram-se em uma obra organizada por Palú, Shutz e Mayer (2020), que se ocuparam de realizar uma coletânea inaugural com os primeiros estudos acerca de todos os desafios enfrentados pelo contexto educacional em tempos de pandemia.

Alves e Barbosa (2020) propuseram um estudo sobre a gestão escolar democrática frente à nova situação socioeducacional do país. Os autores defendem a necessidade de implantação de processos educacionais significativos, mesmo frente ao isolamento social demandado. Acreditam que compete à gestão escolar o desafio de propostas que contemplem planos educacionais emergenciais desafiadores, envolvendo todos os atores sociais - escola, alunos e famílias. Defendem a persistência da gestão democrática participativa, mesmo respeitando a distância necessária, enxergando nesta ação uma alternativa e uma ferramenta para o enfrentamento do retorno às aulas, que será marcado por conflitos pedagógicos, sociais, emocionais e culturais.

Arruda (2020) destacou a crise do capitalismo na educação, causada pela pandemia, propondo reflexões entre as diferenças estabelecidas entre a educação pública e a privada. 0 autor acredita que a inoperância da educação pública, quando comparada à privada, em tempos pandêmicos, vem intensificando a fragilização desse espaço institucional e escancarando amplamente a desigualdade, principalmente em relação às práticas pedagógicas adotadas que possam garantir resultados positivos, vindo significar um grande dano para os sujeitos envolvidos 
e, principalmente, uma grande preocupação para a gestão escolar, que se vê pressionada à tomadas de decisões, contudo, sem recursos, sem materiais e sem políticas públicas (em funcionamento, pelo momento) que garantam o êxito de suas funções e de suas atividades em todas as dimensões em que atua.

Baldin, Pedersettu e Silva (2020) enalteceram os problemas sociais e psicossociais trazidos pela ruptura do vínculo entre escola e alunos e suas famílias. Os autores enaltecem a escola como espaço de convivência, facilitador e promotor da interação e, consequentemente, da aprendizagem enquanto resultante de experiências concretas que neste espaço acontecem. Assim, a gestão enfrentou dificuldades para propostas que mantivessem o sentido de vínculos existentes entre escolas e alunos e família. Inicialmente, registraram muitos alunos com recusa à modalidade de aulas remotas. A partir daí, realizaram uma breve pesquisa junto aos alunos e suas famílias para a tentativa de realização de projetos para aulas não presenciais que fossem capazes de minimizar os impactos sociais e psicossociais resultante do advento pandêmico. Em avaliação, a gestão registrou a ação como uma experiência desafiadora, frente ao cenário caracterizado como inseguro, enxergando na democratização de opiniões de pais e alunos para constituição de projetos uma forma de mostrar o vínculo existente entre eles e a escola, necessário para o período.

Couto, Couto e Cruz (2020) contemplaram em seus estudos o movimento "\#Fiqueemcasa" como de duplo sentido, evidenciando a promoção da saúde em coletividade, contudo, escancarando o descumprimento da democracia e cidadania - que no caso, para os autores, democracia e cidadania digital. Afirmam que o movimento para isolamento social fora realizado em planejamento e racionalidade, inicialmente pela emergência do momento. Entretanto, foram poucas as escolas, representadas por meio de seus gestores, que se prontificaram, de modo imediato, ao enquadramento tecnológico-digital. Muitos gestores escolares não acreditavam na extensão temporal da pandemia e não se organizaram prontamente para o advento.

Os autores alegam, em pesquisa, que a gestão escolar que se organizou de forma mais rápida e não adiou as ações estratégicas ciberculturais necessárias para que o processo de ensino e aprendizagem tivesse continuidade sofreram menos impactos e dificuldades, se comparadas às escolas em que a gestão escolar demorou para propor e executar tais ações. Os impactos e dificuldades foram em todas as dimensões, tendo esta gestão escolar 'atrasada' enfrentamento de problemas com: desenvolvimento dos estudantes; replanejamento do calendário escolar; adequação às inovações tecnológicas para propostas pedagógicas; dificuldade de adaptação ao home office; fragilidade das relações entre as partes envolvidas (escola-docência; docênciaalunos/pais; escola-alunos/pais); evasão escolar e inadimplência, comprometendo resultados financeiros-administrativos; e aproveitamento e rendimento dos estudantes, comprometendo resultados acadêmicos.

Firmino (2020) elencou, brevemente, os desafios do gestor escolar em tempos de aprendizagem remota. Destacou a questão da instabilidade emocional dos sujeitos envolvidos no processo de ensino e de aprendizagem - alunos e familiares -, vindo esta ser considerada como uma prioridade para a docência, transpondo o processo pedagógico para segundo plano. Assim, é grande a demanda pela lida do professor com ansiedades, dificuldades, omissões ou descompromissos dos alunos (e familiares), exigindo-Ihe um preparo que foge de sua competência (ou seja, foge da sua formação pedagógica inicial).

Para a autora, este processo de orientação pedagógica exigido da docência em tempos de pandemia vem ocupando parte do tempo que os professores deveriam dedicar para o processo de 
ensino e de aprendizagem, bem como para demais ações pedagógicas envolvidas - como por exemplo, planejamentos. A gestão escolar precisou intervir, de forma emergencial, para apropriarse desta função, interceptando e contornando as dúvidas e ansiedade dos pais. Para tanto, segundo Firmino (2020), o gestor precisa adotar uma postura crítica em relação aos sujeitos envolvidos e tomar decisões condizentes com o beneficiamento da coletividade. Precisa criar diálogos para decisões democráticas, ampliação da participação, respeitando as partes envolvidas, mas, não se esquivando da hierarquia de funções existentes. Em síntese, para a autora, o gestor deve se flexibilizar frente ao processo, mas nunca esquecer de sua autoridade para a manutenção da ordem e da funcionalidade de uma educação de qualidade e de um ambiente propenso para que isso ocorra.

Franco e Franco (2020) trouxeram as dificuldades em relação à condução da educação especial no período pandêmico, destacando o desafio do processo inclusivo em tempos de isolamento social. Para os autores, a pandemia veio escancarar uma situação de exclusão que, mesmo com a evolução da legislação, permeia na sociedade, inclusive no âmbito da educação. 0 que para os gestores já era uma questão desafiadora, com o distanciamento social veio potencializar um problema que mais se agravará com o retorno às aulas. Os autores acreditam que a gestão escolar precisará de projetos exitosos para a (re)inclusão de alunos que já participavam de um processo em construção permanente, sendo que a ruptura da mesma veio representar um retrocesso na conquista de direitos, na progressão de políticas públicas e na promoção de inclusão visando aprendizagem, sobretudo pautada em democracia e cidadania.

Giordano (2021) destacou os desafios do trabalho dos gestores no contexto pandêmico, inclusive em relação à manutenção dos números de matrículas, execução das atividades pedagógicas propostas e prevenção da evasão escolar. Alegou que a inadimplência, a evasão de matrículas para a rede pública e a evasão de matrículas da Educação Infantil vêm sendo dificuldades administrativas representativas para a gestão escolar privada. Para o estudioso, nesse contexto, as escolas privadas passaram a competir não somente contra outras escolas privadas, mas a enfrentarem as escolas públicas enquanto concorrência para o período pandêmico, considerando o grande número de transferências de alunos registrado em 2020, da educação do âmbito privado para o público.

Kirchner (2020) expôs os desafios da gestão de pessoas durante a pandemia no contexto da educação, evidenciando a educação pública. Destacou a dificuldade em relação à conscientização da docência em relação à elaboração de material didático adequado para os alunos, considerando que nem todos disporiam de recursos tecnológicos de imediato. Assim, a gestão precisou criar grupos de trabalhos coletivos, respeitando o distanciamento social, é claro, mas com êxito na produção dinâmica para suprir a lacuna da escola junto aos alunos rapidamente. Entretanto, sem dúvida, a falta de comprometimento das famílias (pais e responsáveis) na busca de material escolar (as apostilas formuladas) na escola representou uma dificuldade inicial para com a organização da docência. A gestão teve que se organizar, a partir de tal experiência, para visitas e entregas dos materiais de alunos que não procuraram a escola para a retirada.

Oliveira et al. (2020) enalteceram a necessidade da mudança de paradigma da gestão escolar, atentando-se para a necessidade da gestão 4.0 - ou seja, de uma gestão pautada na tecnologia como aliada no processo de enfrentamento dos impactos e desafios caudados pela pandemia na educação. Além disso, segundo os mesmos autores, a reconfiguração dos espaços e tempos educativos na formação de crianças, adolescentes e jovens que cursam a Educação Básica para o momento online, ainda que com recursos e tecnologia digital disponível, tem um impacto grande no seu processo educativo - quer seja na educação pública ou privada. 
Peres (2020) identificou os novos desafios da gestão escolar e das salas de aula em tempos pandêmicos, inclusive dificuldades relacionadas à exaustão dos professores que estão com trabalho redobrado nesse período. O fato é que a gestão não pode se esquivar da preocupação em relação às melhorias dos índices educacionais e, para isso, precisa contar com a sua docência enquanto parceria - que se ocupa da transposição das aulas presenciais para virtuais (nem sempre preparada para o impacto).

Assim, o desafio da gestão escolar em tempos pandêmicos vem sendo dar suporte para a docência para que possa materializar a eficácia e a eficiência do processo de ensino e aprendizagem, principalmente considerando a grande concorrência que existe no mercado da Educação Básica privada. Junto à dimensão pedagógica e de resultados, o gestor não pode estar apático à dimensão de pessoas, considerando a necessidade de administrar angústias, insegurança e estresse laboral da docência (PERES, 2020).

Pralon (2020) destaca o clima organizacional como uma das dificuldades que mais impactou a gestão escolar no período pandêmico. Explica que as dificuldades provêm das limitações impostas pelas condições de trabalho da docência e pelas dificuldades de implantar as novas metodologias - o que vem comprometer resultados e avaliações administrativas acerca da qualidade da educação. Tais dificuldades demandam ações corretivas da gestão, impondo um novo sistema de trabalho e qualidade frente à uma situação que, em muitos casos, é precária. Assim, para o autor, tais dificuldades agregam às incertezas e inseguranças do processo pedagógico e agravam o desenvolvimento econômico-financeiro da escola, requerendo ações emergenciais da gestão, para promover reestruturações que promovam melhoria da qualidade da educação, mediante melhoria das metodologias de ensino e inovação, além de permissão à autonomia da docência - tudo isto resultando em uma melhoria no clima organizacional da instituição, que passa a se configurar e funcionar como virtual/digital.

Ribeiro e Andrade José (2020), por sua vez, também identificaram os desafios do trabalho da gestão escolar no enfrentamento do Covid-19, destacando desafios financeiros, como a inadimplência e as transferências de alunos da educação privada para a educação pública. Os autores acreditam que a concorrência na educação privada na Educação Básica se intensificou no período pandêmico, pois as escolas precisaram mostrar qualidade, inovação e criatividade e nem sempre estiveram preparadas. Os pais, insatisfeitos e inseguros, optaram pela transferência dos filhos para outras escolas de menor custo ou escolas púbicas, diante da insegurança econômica e da insegurança de como a escola privada estaria dando conta de cumprir com as suas propostas, planejamentos e objetivos delineados para o ensino presencial. Frente a essa contextualização, a gestão escolar vem sofrendo pressões, não só para a manutenção das matrículas, mas para ações estratégicas que contornem e revertam os grandes índices de inadimplência registrados no momento.

Silva, Petry e Uggioni (2020) promoveram um estudo acerca dos desafios da educação em tempos de pandemia e identificaram acesso e conhecimento da tecnologia enquanto a dificuldade da conexão de professores para o trabalho enquanto impacto na educação, denominando-os professores desconectados. Além disso, os mesmos autores enalteceram a questão da diferença da escola pública com a privada, associando maiores dificuldades para a educação pública e para seus gestores, alegando escassez de recursos para investimentos em tecnologia necessária para a continuidade da educação, ou seja, identificam a dificuldade pedagógica do processo

Silva e Weinman (2020) relataram a dificuldade de manutenção da gestão democrática em tempos de pandemia, dando destaque aos desafios enfrentados pela gestão pública. Para os 
autores, o distanciamento social exigido como medida sanitária veio comprometer os pilares da educação pública, caracterizada como aberta aos sujeitos que dela se utilizam para decisões que beneficiem a coletividade. Esta foi interrompida, dificultando para a gestão a prática de diálogos, participações e propostas de caminhos pedagógicos e discussões de projetos permeados pelos anseios de seus atores envolvidos.

Valle e Marcom (2020) registraram os desafios da prática pedagógica e da necessidade de desenvolvimento de competências para ensinar em tempos de pandemia. A gestão precisou repensar, rapidamente, formas para capacitar sua docência em relação à demanda pelo exercício de novas competências, não comprometendo o rendimento e processo de ensino e aprendizagem do ano escolar. Nas palavras dos autores, a gestão precisou despertar na docência a conscientização do uso de talentos para "salvar" o ano letivo, não deixando de encorajá-la e apoiala frente ao novo e inusitado. $O$ desafio foi o romper com práticas habituais para inovação frente à demanda. Nesse interim, coube à gestão o cuidar de inquietações da docência, assistindo-a da melhor forma, disponibilizando recursos essenciais e necessários.

Andrade et al. (2021) promoveram estudos cujo resultado vem apontar a necessidade de (re)construção das práticas docentes sendo destaca como a maior dificuldade enfrentada pela gestão escolar em período pandêmico. Os autores afirmam que a demanda pela criatividade e inovação da docência para o enfrentar as diversidades colocadas à tona pela pandemia significou um grande impacto, demandando veemente atuação da gestão escolar para propostas de intervenção. Este desafio foi provido da recusa e da dificuldade que a docência apresentou para adequação e aderência às novas formas tecnológicas de ensinar. A gestão escolar foi desafiada a comprovar para a docência os benefícios do processo pedagógico realizado por meio de mídias digitais e, por isso, precisou capacitar rapidamente seu quadro de pessoal; entretanto, mesmo assim, ainda encontrou recusa e dificuldades por parte da docência frente à adesão.

Borges, Figueiredo e Avelino (2021), em estudo acerca dos gestores em escolas de ensino integral no estado de São Paulo durante a Pandemia da Covid-19, registraram a necessidade do uso das tecnologias para facilitar as práticas pedagógicas, sendo esta uma função do gestor escolar para com a motivação junto à sua docência. Contudo, registraram a dificuldade de ambas as partes: tanto da gestão, que não se preparou para o imprevisto do acontecido, quanto da docência que rejeita atualizações digitais.

Os autores destacaram que muitos gestores tiveram que aprender a trabalhar frente às novas plataformas e, da mesma forma, enfrentaram tais dificuldades com a rejeição da docência para com a adequação para esta nova forma de trabalho. Asseguram que esta dificuldade comprometeu a dimensão resultados, impactando no rendimento dos alunos, haja vista ter afetado o desenvolvimento pelo processo de ensino e aprendizagem em defasagem e atrasado pela tardia adequação e remodelação do processo pedagógico. O resultado do estudo promovido traz recomendações acerca da necessidade da gestão em ações para o despertar do interesse do uso das ferramentas digitais em todos os sujeitos envolvidos no contexto e na comunidade escolar (BORGES; FIGUEIREDO; AVELINO, 2021).

Diodato et al. (2021) também realizaram um estudo acerca dos reflexos da pandemia frente e às implicações da gestão democrática na construção do projeto político pedagógico e os reflexos da pandemia. Os autores acreditam que a pandemia veio impactar a gestão em relação ao seu cumprimento na participação de todos os atores envolvidos em decisões, justamente pela condição do distanciamento social - comprometendo as ações de sua dimensão administrativa e da sua dimensão cultura organizacional e pessoas. Registraram a dificuldade e, até mesmo, a 
impossibilidade do cumprimento de uma ação coletiva no final do ano de 2020 para a construção de projetos pedagógicos para o ano de 2021. Esta dificuldade deixou, em lacuna, a busca por uma alternativa que se cumprir os princípios da gestão democrática no âmbito escolar, enxergando nas ferramentas tecnológicas uma alternativa para, senão resolver, sobretudo amenizar a condição da gestão.

Ainda, no mesmo estudo, os autores destacaram que cabe ao gestor escolar cuidar da promoção da participação de todos que estejam envolvidos no processo de ensino e aprendizagem. Afirmam que todos devem participar da elaboração desde o currículo até às decisões mais burocráticas para que o estilo de gestão adotado nos dias de hoje seja cumprido, principalmente em tempos pandêmicos (DIODATO et al., 2021).

Ferraz, Araújo e Motta (2021), em estudos sobre a regulação do trabalho pedagógico em tempo de pandemia, destacaram as atribuições da gestão em relação à comunicação junto à equipe pedagógica. Relataram que este processo, a princípio impactado, encontrou nas ferramentas de comunicação online ponto de apoio. A gestão encontrou nas redes sociais e nos aplicativos de mensagens, embora não previstos para o trabalho de cargos e funções, uma alternativa para comunicação de equipe pedagógica e, pelo sucesso, estendeu este canal de comunicação para a comunidade de alunos e pais. Entretanto, a gestão encontrou dificuldades quando os professores passaram a integrar grupos de comunicação de pais (como por exemplo, o grupo de WhatsApp de pais de determinada sala). A docência reclamou de precisar trabalhar fora do período, não sendo respeitada a privacidade dos professores por parte dos pais, principalmente das crianças de Ensino Fundamental.

Gabriel et al. (2021), realizaram um comparativo entre o ensino público e o privado no póspandemia, alegando que a gestão das escolas públicas sofreu mais impactos e enfrentou mais dificuldades do que a gestão das privadas. Assegura que o contratempo sanitário simbolizou uma ocasião propensa à uma série de desconstruções que foram realizadas anteriormente; principalmente de desconstrução de relações e de conhecimento. Para os autores, o período que chamam de pós-pandemia nas escolas (ou seja, o período de aulas que passou a acontecer com o isolamento social) permitiu uma regressão de aprendizado e de transformações. Acreditam que, para a gestão, contornar e retomar o contexto será uma tarefa árdua e que demandará de estratégias de ações em todas as dimensões da gestão.

Reis e Leal (2021) asseguraram que a pandemia veio impactar a gestão escolar quanto ao cumprimento da democracia, principalmente da democracia digital - o que veio comprometer o exercício de cidadania, infringindo os princípios da gestão moderna. Afirmam que a dificuldade de acesso aos recursos eletrônicos, sendo estes essenciais para o momento, impactaram a extensão dos estudos em casa. Enaltecem esse momento de pandemia como de não cumprimento de inclusão, relacionando o movimento como inclusão digital de todos, inclusive para famílias com rendas mais baixas. O não cumprimento da democracia digital promoveu repercussões em muitas dimensões da gestão, principalmente pedagógica e de resultados.

Ainda, os mesmos autores destacaram as dificuldades da docência (mais antiga) em relação às habilidades necessárias junto aos recursos tecnológicos, materializando um grande desafio para a propagação dos conteúdos didáticos com uso dos recursos das mídias digitais. Esta colocação, segundo Reis e Leal (2021), vem impactar nas atividades da gestão escolar, sendo necessário um trabalho paralelo para com as dimensões administrativa, de cultura e clima escolar e de pessoas.

Silva, Silva e Gomes (2021) elencaram as dificuldades enfrentadas pela gestão escolar de forma geral. Os autores enumeraram os desafios atuais da gestão escolar, não deixando de 
considerar que estes podem se agravar como o movimento de retomada ao processo de educação presencial em um futuro breve. Acreditam que a gestão enfrentará dificuldades relacionadas às dimensões já elencadas, sendo as principais: desenvolvimento pleno dos estudantes (aprendizagem); retomada de conteúdos e práticas (currículo); estresse emocional/laboral de equipes; estresse emocional de estudantes; fragilidade nas relações; (re)planejamento e (re)organização escolar; evasão, inadimplência e concorrência (saúde financeira da escola); queda nos resultados de modo geral e; dificuldade de retomada na busca por resultados.

Em síntese, as discussões propostas e apresentadas por estes 22 trabalhos permitiram compreender que, muito embora todos se referissem à experiências vividas no contexto da pandemia da Covid-19 em escolas de Educação Básica, cada um deles apontava para questões particulares, quer seja do movimento de gestão dos processos de ensino e de aprendizagem, quer seja das formas de lidar com um momento repleto de incertezas. No entanto, todos eles foram fundamentais para compreender os desafios e as possibilidades que este cenário pandêmico tem proporcionado no sentido de subsidiar as análises aqui realizadas e de fomentar novas reflexões, estudos e práticas que se originam, também, desta pesquisa.

\section{METODOLOGIA}

O presente artigo trata de uma pesquisa aplicada (THIOLLENT, 2009), de abordagem qualitativa (CRESWELL, 2010). O caráter aplicado relaciona-se à prática do estudo em âmbito educacional, haja visto o envolvimento dos gestores escolares de escolas privadas de Varginha-MG enquanto sujeitos da pesquisa, para conhecimento em profundidade acerca dos desafios e impactos da pandemia do Covid-19 na gestão escolar. A abordagem qualitativa se deve à busca da complexidade das tendências e reflexos da pandemia do Covid-19 na educação e, especificamente, na gestão das escolas privadas, que se mantém a partir do pagamento de mensalidades das famílias dos alunos, situação agravada por esse fenômeno. Assim, para a investigação de detalhes junto aos gestores escolares, justificaram-se tais abordagens.

Os participantes desta pesquisa são gestores de escolas privadas de Varginha-MG, pertencentes a 41 a SRE. No início do ano de 2021, totalizavam 30 escolas privadas no município, todas localizadas na zona urbana. Todos os 30 gestores foram convidados a participarem da pesquisa, cujo critério para a sua participação foi o aceite formal a este convite - ou seja, a adesão de convite. Devido à diversidade de realidade das escolas em questão, esperava-se que todos participassem da pesquisa, no entanto, 5 escolas, do segmento de Educação Infantil, fecharam e 19 escolas se negaram ou não responderam ao contato para participar da pesquisa. Devido a este contexto, somente seis diretores de escola, equivalente a $20 \%$ da totalidade planejada, aceitaram participar da pesquisa, que foi submetida ao Comitê de Ética em Pesquisa do Centro Universitário do Sul de Minas e aprovada sob o número 4.850.118.

Para coleta de dados, foi aplicado um questionário online, elaborado no Google Forms, com o objetivo de: (i) realizar um levantamento sociodemográfico dos participantes, incluindo informações sobre a formação acadêmica e atuação profissional; (ii) mapear e caracterizar o perfil das escolas envolvidas na pesquisa; (iii) investigar a compreensão dos gestores sobre as dimensões da gestão escolar e suas formas de agir na escola e; e (iv) compreender os desafios e os impactos da gestão escolar agravados em virtude da pandemia do Covid-19. Os dados foram analisados considerando a técnica da análise de conteúdo, como apresentados a seguir. 


\section{RESULTADOS E DISCUSSÃO}

\subsection{Os Gestores Escolares}

Dos seis Gestores, participantes desta pesquisa, cinco são do sexo feminino e um do sexo masculino. Nessa perspectiva, estes dados aproximam-se do que apontam os estudos de Gatti et al (2019), em que, do público que trabalha na gestão escolar, a maioria é composta por uma parcela evidentemente feminina. A título de preservar-lhes a identidade, será adotada a nomenclatura Gestor ou Gestora, acrescida de um numeral para se referir a eles no decorrer do trabalho.

Em relação às idades, pode ser observado que, em ordem crescente, o gestor mais novo possui idade entre 41 e 45 anos, um possui entre 46 e 50 anos, um entre 51 e 55 anos, ao passo que três possuem idades que variam de 56 a 60 anos.

Sobre o tempo em que cada participante atua como Gestor Escolar, três atuam na profissão de Gestor Escolar entre 11 e 15 anos, enquanto dois, entre 21 e 25 anos, e um, entre 26 e 30 anos. Já em relação à atuação enquanto Gestor Escolar na escola que lidera atualmente, observa-se, iguamente, uma variação temporal, três participantes responderam que atuam na escola por menos de 5 anos enquanto Gestores Escolares, enquanto um atua entre 6 a 10 anos. Somente dois possuem tempo similar de Gestão Escolar e de atuação na mesma escola, que é o tempo entre 21 a 25 anos.

Perguntados sobre quais principais qualidades o definem como gestores, os respondentes justificaram habilidades relacionais em sua maioria, como pode ser observado nas narrativas das Gestoras 1, 2, 3 e 5 e do Gestor 4. Ter conhecimento foi uma qualidade observada pela Gestora 3 e responsabilidade, engajamento e transparência foram mencionados, ainda, pela Gestora 6:

Acho que minhas habilidades relacionais me fazem uma boa gestora (Gestora 1).

Ser acessível (Gestora 2).

Conhecimento (Gestora 3).

Saber ouvir e entender as pessoas. discernimento nas tomadas de decisão (Gestor 4).

Empatia e habilidade em lidar com conflitos (Gestora 5).

Responsabilidade/ engajamento / transparência/ humanização e empatia (Gestora 6).

Ao analisar as respostas dos seis gestores, é possível observar as considerações de Libâneo (2017), que esboça o perfil do gestor escolar como alguém sempre aberto ao diálogo e promotor de escuta ativa de sua equipe, na intenção de buscar melhorias na educação.

Ao mesmo tempo, é possível verificar que estas afirmações dos gestores também se aproximam dos estudos de Souza (2020), quando o autor explica que o perfil do gestor escolar há de ser autoconfiante, dominador de seus pontos fortes e consciente de seus pontos fracos, buscando equilibrá-los para a promoção da qualidade almejada, com a ajuda dos demais sujeitos em seu entorno e no ambiente envolvidos. 


\subsection{As Escolas}

Quanto à descrição do perfil das escolas pesquisadas, lideradas pelos gestores participantes desta pesquisa, todas são de iniciativa privada: quatro existem há mais de 41 anos, enquanto duas foram fundadas entre 21 e 25 anos.

Os participantes responderam que na escola em que atuam como Gestores Escolares, há uma variação entre as etapas de ensino atendidas no tocante à Educação Básica (Educação Infantil, Ensino Fundamental, Anos Iniciais e Finais, e Ensino Médio).

É possível observar que das seis escolas, quatro abrangem todas as etapas da Educação Básica, que são: Educação Infantil, Ensino Fundamental - Anos Iniciais (1a ao 5o ano) e Ensino Fundamental - Anos Finais (6으 ao 9ㅇano) e Ensino Médio, como pode ser observado na Figura 1.

Figura 1 - Etapas de ensino atendidas por escola pesquisada

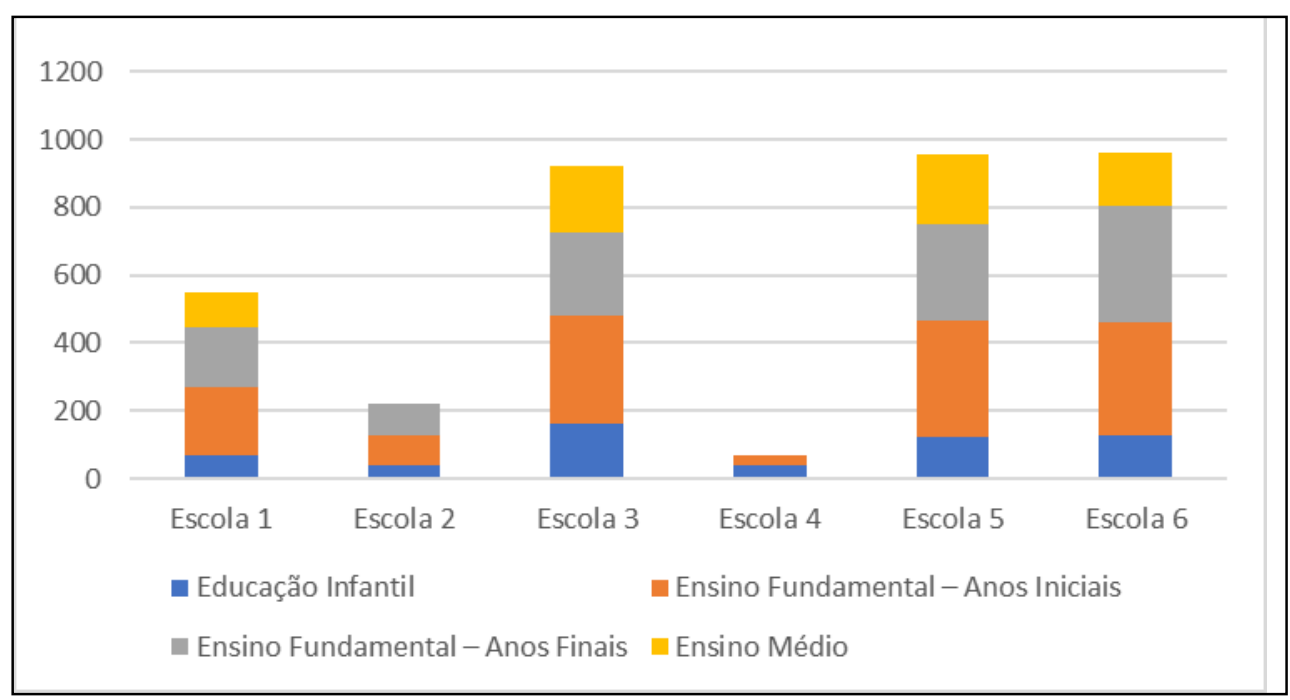

Fonte: Dados da pesquisa

Observando a Figura 1, verifica-se que a Escola 2 não atende ao Ensino Médio e a Escola 4 atende apenas a Educação Infantil e o Ensino Fundamental - Anos Iniciais (1a ao 5o ano). Nessas escolas, o número menor de matrículas para o ano de 2021 foi 70 alunos, enquanto o maior número foi 962 matrículas para o referido ano.

Quanto a quantidade de professores por etapa de ensino que as escolas possuem, observa-se uma variação entre 10 e 76 docentes, distribuídos ao longo de toda a Educação Básica, como pode ser observado na Figura 2.

Analisando a Figura 2, é possível verificar que a quantidade de docentes é proporcional às etapas de ensino oferecidas pelas escolas e a quantidade de alunos que as escolas possuem. A Escola 6, nesse sentido, possui o maior número de docentes, enquanto a Escola 4, o menor. 
Figura 2 - Quantidade de professores que compõem a equipe pedagógica das escolas

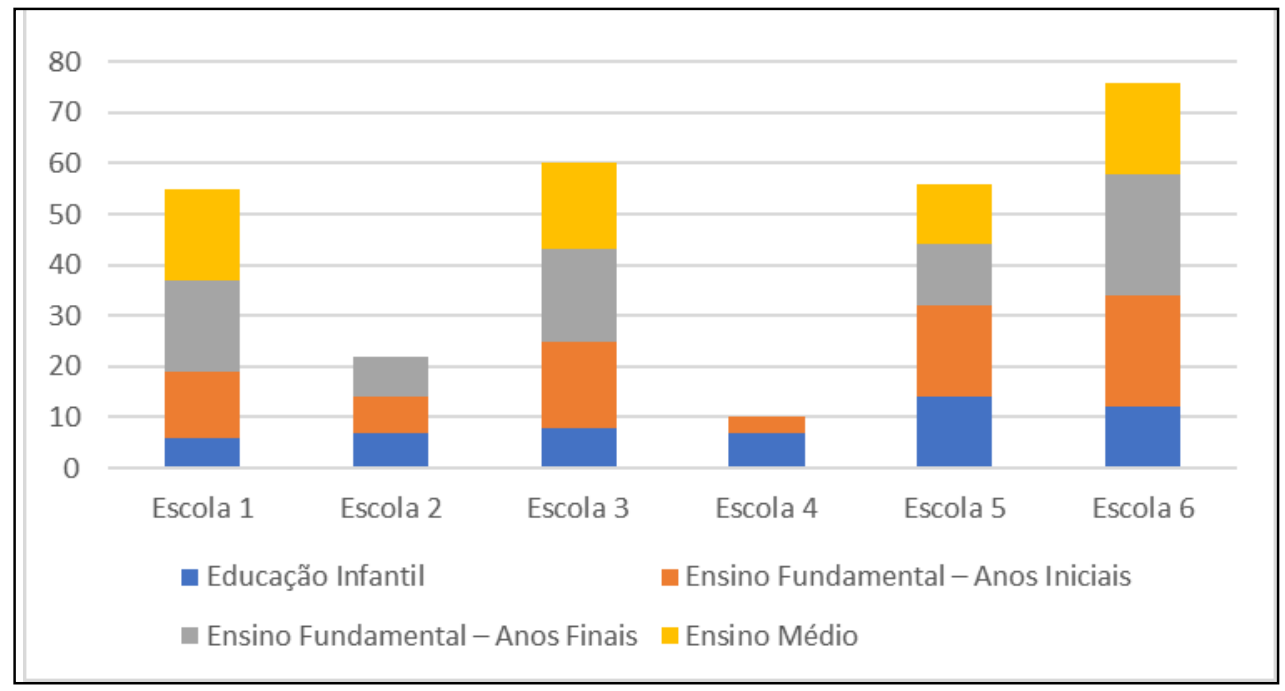

Fonte: Dados de pesquisa.

Em relação à equipe pedagógica que atua nas escolas pesquisas (excluindo-se os docentes), é possível verificar uma diferença quanto a quantidade de profissionais em cada uma das escolas, como pode ser observado na Figura 3.

Figura 3 - Quantidade de funcionários que compõem a equipe pedagógica das escolas

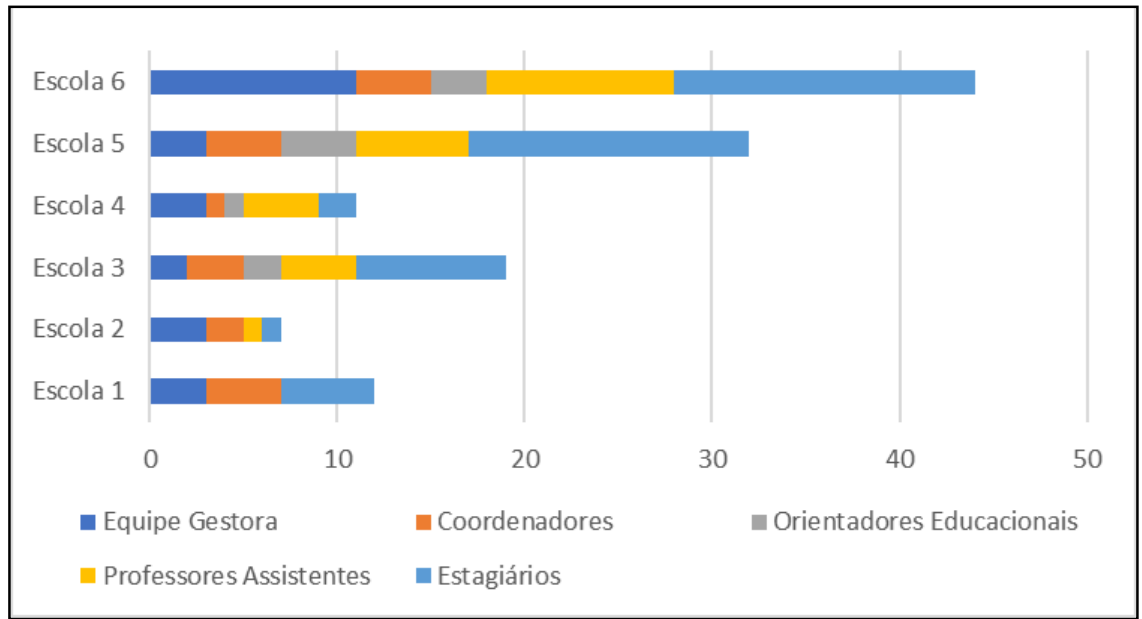

Fonte: Dados de pesquisa.

Observa-se na Figura 3 que a Escola 6 é a que possui o maior número de funcionários pertencentes à equpe pedagógica, ao passo que a escola 2 é a que mantém o menor número. As Escolas 1 e 2 não possuem Orientadores Educacionais e a Escola 1 não possui Professores Assistentes. Um dado interessante dessas escolas é o alto número de estagiários contratados, que supera, inclusive, o número de professores assistentes, com exceção da Escola 4.

Em relação à quantidade de funcionários que atuam em áreas administrativas e operacionais, é possível observar um equilíbrio entre a quantidade de colaboradores que atuam na secretaria da escola e uma diversidade em relação à limpeza e cozinha, como pode ser observado na Figura 4. 
Figura 4 - Quantidade de funcionários que atuam em áreas administrativas e operacionais.

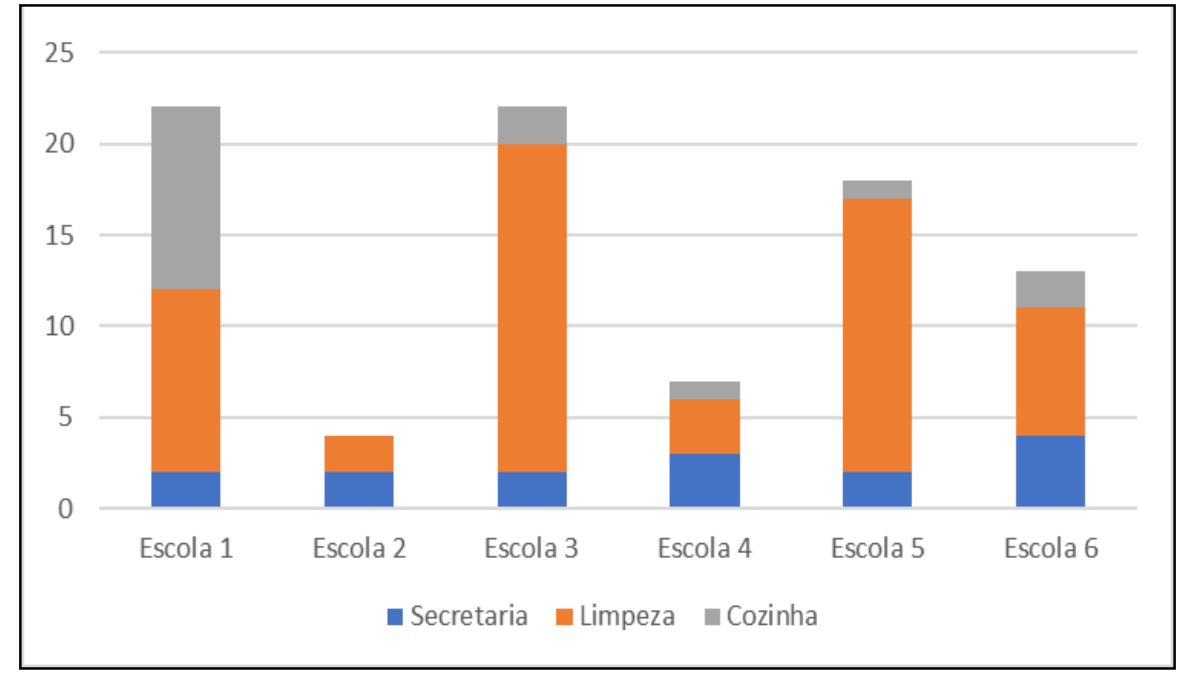

Fonte: Dados de pesquisa.

Quando observados os dados presentes na Figura 4, verifica-se que há uma variação significativa na quantidade de funcionários que integram as equipes de limpeza das escolas, o que parece ser proporcional à quantidade de alunos e funcionários atendidos por elas. Quanto à equipe de cozinha, apenas a Escola 2 não possui funcionário específico para esta atividade.

\subsection{As dimensões da Gestão Escolar na perspectiva dos gestores}

A fim de procurar compreender qual era a concepção de Gestão Escolar por parte dos participantes e como eles analisam suas práticas de gestão, os gestores escolares foram inquiridos se consideravam sua gestão democrática. Metade dos participantes afirmou que "sim" e metade afirmou que considerava "em partes".

Havia uma opção de resposta que era "não", mas nenhum gestor assinalou esta opção. Ainda assim, além de responderem "sim" ou "em partes", os respondentes precisaram justificar sua resposta. A Gestora 5 e o Gestor 4 justificaram a escolha do "em partes" considerando que algumas ações partem deles, sem antes haver participação de outros setores da escola.

Alguns princípios não são negociáveis (Gestor 4).

Algumas decisões são compartilhadas, outras não (Gestora 5).

Já a Gestora 1 apenas disse considerar "em partes" sua gestão como democrática por não haver criado ainda fóruns de participação, conforme pode ser visto a seguir:

Ainda precisar implementar alguns fóruns de participação, como Grêmio ou conselho de alunos, escola de pais, entre outros. (Gestora 1)

Os gestores que consideram sua gestão como participativa apontaram o trabalho em equipe como uma característica de sua atividade na escola, como pode ser observado a seguir:

As decisões são tomadas pela gestão pedagógica a partir das solicitações dos professores (Gestora 2). 
As decisões e orientações são construídas e compartilhadas em equipe (Gestora 3).

Nossa política de trabalho é focada no sentido de equipe, na unidade permanente, valorização do profissional e buscando sempre o sentimento de pertencimento. Juntos sempre mais fortes! (Gestora 6).

Ao observar as afirmações dos gestores em relação à própria atuação como totalmente democrática, verifica-se a presença dos elementos "participação" e "equipe", como preponderantes nos dicursos. Estes elementos estão presentes nos estudos de Lück (2009), ao salientar que o trabalho colaborativo se configura como uma premissa das práticas de gestão democrátiva. Libâneo (2017) também acredita que o gestor que esteja em pleno exercício de suas habilidades não pode dissociar-se de um perfil democrático, o que nota-se que não ocorreu, de acordo com os segmentos de falas dos gestores participantes.

Ao mesmo tempo, os três gestores que afirmam que sua gestão é democrática "em partes" e justificaram isso dizendo que existem decisões que precisam ser tomadas exclusivamente pelo diretor da escola, demonstram que também entendem que nem todas as decisões realizadas na escola são, de fato, coletivas. Para eles, há momentos em que o cargo de Gestor Escolar traz, consigo, a responsabilidade pelas tomadas de decisão.

Na perpectiva de Alves e Barbosa (2020), os gestores devem construir ações características de uma gestão democrática participativa. Para eles, é preciso entender as diversidades de papéis e responsabilidades no exercício cotidiano, o que torna, muitas vezes, necessária uma certa distância. No entanto, perceber quando esta distância é, de fato, necessária e quando o trabalho colaborativo é essencial, se torna essencial para o enfrentamento do retorno às aulas, por exemplo, o que, para os autores, pode marcado por conflitos pedagógicos, sociais, emocionais e culturais. Entretanto, quando o Gestor 4 afirma que "Alguns princípios não são negociáveis" e a Gestora 5 que "Algumas decisões são compartilhadas, outras não", denotam que a gestão não seguiu padrões democráticos.

Assim como o apresentado pelos estudos de Silva e Weinman (2020), a dificuldade da manutenção da gestão democrática por alguns gestores pode ter se dado por conta do distanciamento social imposto, dificultando a prática do diálogo, da participação e das propostas de encaminhamentos pedagógicos. Isso pode ter inviabilizado as discussões colaborativas no contexto da escola e fomentado uma prática de decisões pelos gestores para serem cumpridas pela coletividade.

Quando questionados sobre quais dimensões da Gestão Escolar mais desempenhavam e quais mais delegavam, observou-se um empate em Gestão de Pessoas e Gestão Pedagógica. Quando as consideram mais fáceis de serem colacadas em prática, a mais votada foi Gestão de Pessoas, mencionada por três participantes.

Quando discorre sobre Gestão de Pessoas, opção mais votada pelos respondentes, Lück (2009) afirma que esta é a dimensão que promove o trabalho coletivo, a prática do relacionamento interpessoal, comunicacional, além de desenvolver ações que congregam de forma colaborativa as diferentes ações no espaço escolar. Esse conceito está impresso nas falas das Gestoras 2 e 6, como pode ser observado a seguir

Com uma boa proposta e comunicação efetiva a gestão de pessoas se torna mais fácil (Gestora 2). 
Nossa gestão é democrática, sempre damos espaço para que todos participem e contribuam com sugestões e ideias. A equipe é muita unida e forte, isso facilita o trabalho de gerir pessoas, mantendo um clima escolar tranquilo e de muita cumplicidade (Gestora 6).

Em contraponto ao trabalho de Kirchner (2020), a gestão de pessoas durante a pandemia, no contexto da educação, gerou muitas dificuldades. Para este autor, houve a necessidade de criação de grupos de trabalhos coletivos, envolvendo professores, funcionários, membros da comunidade e famílias, as quais, nem sempre conseguiram se comprometer com a manutenção das atividades de ensino propostas, sobretudo em relação à busca dos materiais pedagógicos disponibilizados pela escola. Esta situação não foi observada nas narrativas dos gestores participantes desta pesquisa.

As dimensões "Gestão Administrativa" e "Cultura e Clima escolar" obtiveram 25\% de votos dos respondentes quanto a ser consideradas "fáceis" de serem colocadas em prática. Ao analisar os atributos que compreendem cada uma dessas dimensões, pode-se observar uma diferença na forma de vivenciá-las, como pode ser observado na Figura 5:

Figura 5 - Atributos das dimensões "Gestão Administrativa" e "Gestão de Cultura e Clima Escolar"
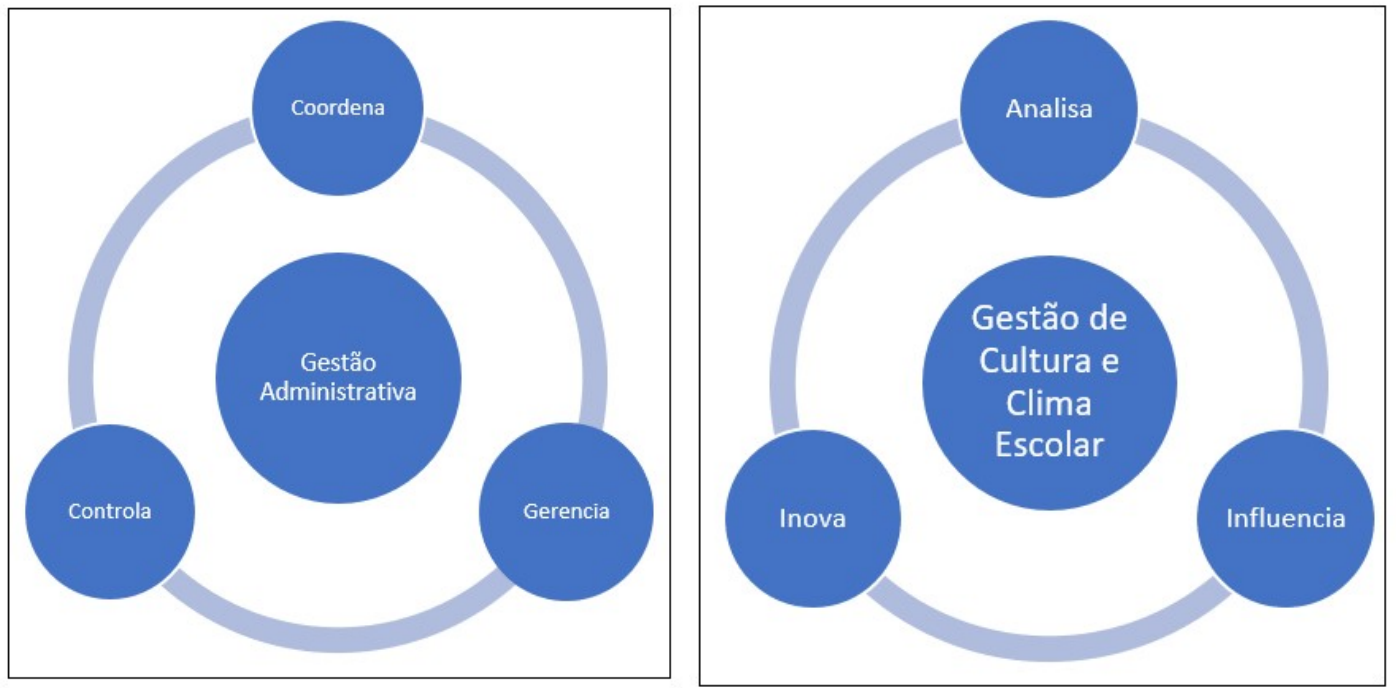

Fonte: Esquema criado pelos autores, adaptado de Lück (2009).

Ao observar os atributos presentes na Gestão Administrativa, verifica-se que, nela, o Gestor Escolar coordena, gerencia e controla os processos. Já na Gestão de Cultura e Clima Escolar, o Gestor analisa, influencia e inova. Embora tenham assinalado estas dimensões como "fáceis", nenhum gestor mencionou justificativas relacionadas à estes processos em suas narrativas, como pode ser observado a seguir:

Não há nada que julgue fácil na gestão escolar. No entanto, no que tange a parte administrativa, se a instituição tem bons funcionários a delegação de funções é mais tranquila. Para as demais, apesar de acreditar que uma gestão mais participativa, democrática e colaborativa é mais eficiente creio ser importante que o gestor acompanhe de perto os trabalhos. Descentralizar ou delegar em nenhum momento pode significar ausência. Um bom gestor é sempre corresponsável pelas ações e resultados da instituição (Gestora 1).

Suporte automatizado dos processos administrativos facilitam (Gestor 4). 
Em relação à Gestão Pedagógica, que "cria na escola um ambiente estimulante e motivador orientado por elevadas expectativas de aprendizagem e desenvolvimento, autoimagem positiva e esforço compatível com a necessária melhoria dos processos educacionais e seus resultados" (LUCK, 2009, p. 59), os gestores escolares que a assinalaram não mencionaram justificativas relacionadas a esta definição. Apenas a Gestora 3 disse que esta dimensão é "prazerosa e incentivadora".

No estudo realizado por Diodato et. al. (2021), a criatividade e a inovação da docência para enfrentar as diversidades colocadas à tona pela pandemia significou um grande impacto na gestão pedagógica, demandando de forma mais incisiva a atuação da gestão escolar para propostas de intervenção, movimento muito semelhante ao observado, também, no estudo que empreendemos.

Em relação às dimensões que consideram menos fáceis, os gestores escolares assinalaram: "Gestão Administrativa", com 42,9\%, "Gestão de pessoas" e "Gestão de Resultados", cada uma com $28,6 \%$ de votos.

As Gestoras 1 e 6 justificaram a Gestão de Pessoas como a mais difícil, como pode ser observado a seguir.

A gestão de pessoas exige equilíbrio, respeito, dedicação, sensibilidade e, ao mesmo tempo, exige dizer não, corrigir, avaliar e isso não é nada fácil. (Gestora 1)

Por mais que a equipe realize um trabalho motivacional e busque a excelência do desenvolvimento dos alunos, dependemos do envolvimento dos educandos e da parceria das famílias. Nem sempre recebemos a resposta desejada para o bom aprendizado, principalmente neste tempo de pandemia. (Gestora 6)

Autores como Libâneo (2017) e Lück (2009) apontam em seus estudos que a Gestão de Pessoas é uma dimensão da Gestão Escolar que exige formação - pessoal e profissional - por parte do Gestor Escolar. Além disso, requer elementos advindos da experiência com aquela equipe, ou seja, conhecimento dos funcionários, da dinâmica da escola, das famílias, dos estudantes e do entorno que envolve a escola.

Para Firmino (2020), o gestor escolar tem um grande desafio: adotar uma postura crítica em relação à sua própria prática e àquela desenvolvida na escola e tomar decisões que favoreçam toda a comunidade educativa. Para a autora, é preciso desenvolver uma capacidade de flexibilização, sem esquecer da posição de liderança que o gestor assume frente ao grupo, o que, na prática, é um movimento bastante complexo. É exatamente nesta dimensão reflexiva que os gestores, participantes desta pesquisa, ponderaram suas narrativas, alternando expressões relativas a procurar manter a organização dos espaços e dos processos gerenciais da escola, ao mesmo tempo em que se preocupavam com a manutenção de uma educação de qualidade.

Da mesma forma, os estudos de Baldin, Pedersettu e Silva (2020) também apontaram a gestão de pessoas como uma dimensão difícil da gestão escolar. Para os autores, considerando a preocupação emocional, talvez a gestão de pessoas tenha sido a de mais difícil manutenção no cenário da pandemia, por causa do medo, do inédito e do desconhecido.

As Gestoras 2, 3 e 5 e o Gestor 4 mencionaram aspectos da Gestão Administrativa como os mais difíceis, como pode ser observado a seguir. 
Devido às várias autorizações, processos administrativos e licenças que precisam ser tiradas principalmente em tempo de pandemia. (Gestora 2)

Parte mais burocrática. (Gestora 3)

Pelas características de cada indivíduo e as variáveis acidentais. (Gestor 4)

Porque dependem de dados, de mensuração para que possam ser fidedignos. (Gestora 5)

A seguir, apresentam-se os resultados referentes à atuação do gestor escolar no contexto da pandemia.

\subsection{Gestão Escolar em tempos de pandemia: uma reflexão sobre ameaças e oportunidades}

Quanto à atuação do gestor no contexto da pandemia, ao serem questionados se se sentiram preparados para este exercício, observa-se uma variação de respostas: 4 gestores afirmaram que estavam preparados para gerir a escola na conjuntura pandêmica, enquanto 2 disseram que estavam preparados "em partes". Nenhum gestor assinalou a resposta "não estava preparado". Por um lado, afirmar que "sim, estava preparado" para conduzir a escola em uma situação de pandemia pode revelar um perfil de gestor que está aberto aos diferentes desafios que a escola pode enfrentar, quer seja do ponto de vista das aprendizagens dos estudantes, do relacionamento com as famílias, quer seja do ponto de vista da gestão de pessoas, do clima da escola ou da gestão administrativa e financeira, dimensões já apontadas por Lück (2009), quando de seus estudos. Por outro lado, afirmar que "sim, estava preparado" ou "estava preparado em partes" pode sugerir que o gestor escolar reconhece que seu papel é um papel de liderança na escola e, por isso, sujeito às diferentes adversidades que podem surgir a qualquer momento.

$\mathrm{Na}$ tentativa de compreender os possíveis motivos que levaram os gestores, participantes desta pesquisa, a afirmarem que se sentiram preparados, ainda que "em partes", para enfrentar o contexto pandêmico, questionou-se sobre quais ameaças gerais e quais ameaças locais os gestores viam como preocupação.

Em relação às ameaças gerais, dos seis gestores, três mencionaram a situação econômica do país, um mencionou as políticas públicas e duas mencionaram questões relacionadas às famílias e ao formato das aulas, como pode ser observado a seguir:

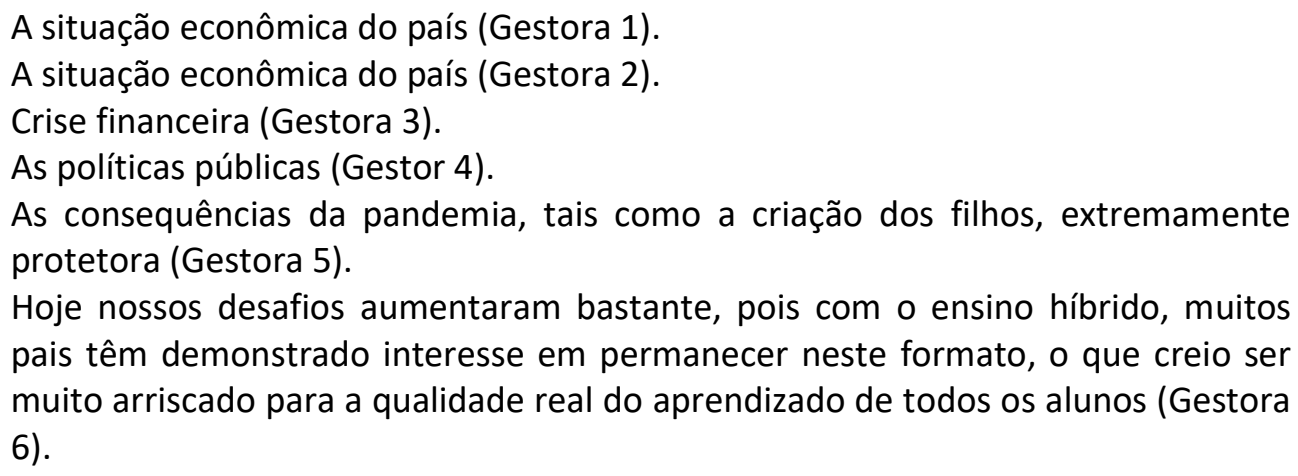

Nas falas das gestoras 1, 2 e 3, é possível notar que os temos "situação econômica" e "crise financeira", quando relacionados ao termo "ameaças gerais", podem estar ligados à pandemia de uma forma geral. Na fala de Ribeiro e Andrade José (2020), os desafios financeiros foram de 
grande impacto, sobretudo com a inadimplência e cancelamento de matrículas, pois muitas famílias optaram por colocarem seus filhos em escolas de menor custo ou, então, em escolas públicas.

Já em relação às "ameaças locais", os respondentes a relacionaram, também, com questões econômicas, mencionando o valor da mensalidade (Gestora 2, 5 e 6), a concorrência (Gestora 3) e o acesso à escola (Gestora 1). Apenas o Gestor 4 afirmou não ver nenhuma ameaça local:

Conseguir um preço acessível que consiga custear os gastos (Gestora 2).

O valor de mensalidade (Gestora 5).

Estamos muito preocupados com a questão econômica do país, a crise política tem nos afetado grandemente. Isso pode interferir na captação de novos alunos, muitos pais têm tido dificuldade em honrar seus compromissos financeiros. Vamos aguardar (Gestora 6).

Concorrência desleal. (Gestora 3)

Talvez, custos com transporte e alimentação, considerando que a escola não é próxima ao centro urbano. Sensação de perigo, considerando que o acesso à escola se dá por rodovia. Para que o citado acima seja neutralizado, a escola realmente tem que caminhar em busca de diferenciais. (Gestora 1 )

Nenhuma. (Gestor 4)

É possível notar, de forma geral, que as ameaças locais se dão a partir da preocupação financeira. Mais uma vez, nas falas de Ribeiro e Andrade José (2020), os desafios financeiros trouxeram bastante impacto para o cenário escolar. Não à toa, isso pode ser visto nas falas dos gestores tanto sobre as ameaças locais quanto gerais.

Por fim, foi perguntado também quais as principais oportunidades para as escolas do segmento privado, na opinião dos gestores, tanto do ponto de vista mais amplo, quanto do ponto de vista local.

Em relação às oportunidades mais gerais, as Gestoras 1 e 6 descreveram oportunidades relacionadas à rápida adaptação das escolas privadas em relação aos recursos e metodologias de ensino adotadas. As Gestoras 3 e 5 apontaram soluções mais gerais, relacionadas a termos como "evolução", "autonomia" e "criatividade", por exemplo. O Gestor 4, mencionou a "socialização infantil" e a Gestora 2 apontou, ao invés de uma oportunidade, uma análise relacionada à "desvalorização da educação pelos governantes" nesse momento, como pode ser observado a seguir:

A capacidade de resposta rápida para o ensino em situação de pandemia fortaleceu e deu maior visibilidade ao ensino privado. As escolas, agora, têm espaço e experiência para inovação (Gestora 1).

Vejo que este tempo de pandemia nos fez sair da zona de conforto e tivemos, em curto espaço de tempo, de reinventar nossas práticas pedagógicas. Isso nos fez enxergar novas possibilidades e valorizar mais as ferramentas tecnológicas. Creio 
que a partir daqui, as metodologias ativas e as estas ferramentas já são partes integrantes de nossas práticas (Gestora 6).

Autonomia, criatividade e parceria (Gestora 3).

A evolução que cada uma conseguiu durante a pandemia (Gestora 5).

A socialização infantil (Gestor 4).

A desvalorização da Educação pelos governantes durante a pandemia (Gestora 2).

Ao analisar as respostas dos gestores, pode-se notar uma congruência ao pensamento de Oliveira et al. (2020), que fala da necessidade da reinvenção em meio aos desafios propostos pelo isolamento social.

Em relação às oportunidades de âmbito local, os respondentes a relacionaram considerando oportunidades de inovação, atreladas à tecnologia e flexibilidade (Gestora 1, 2, 5 e 6), humanização nas práticas (Gestora 3) e localização (Gestor 4):

O colégio não tem o rigor filosófico das escolas confessionais, que são boa parte da concorrência. Isso significa rapidez nas tomadas de decisão, flexibilidade maior para inovar e respeito à diversidade; além de ser uma escola que tem suporte de um grupo universitário (Gestora 1 ).

A estrutura e a Inovação tecnológica (Gestora 2).

A tecnologia educacional e o avanço de processos durante a pandemia (Gestora 5).

A escola que se manter antenada nas inovações, manutenção da boa estrutra física e parcerias com novas possibilidades de aperfeiçoamento de habilidades, essas irão se destacar no mercado. Assim temos caminhado, sempre atentos em manter nossos princípios, valores e na busca constante de oferecer o que há de melhor para nossos alunos (Gestora 6).

Praticar o diferencial (humanização) (Gestora 3).

Oportunidade de localização (Gestor 4).

É possível notar que inovação, diferencial e manutenção de valores foram os termos que os respondentes usaram para avaliarem a situação da escola enquanto gestão na conjuntura pandêmica e se aproximam dos estudos empreendidos por Silva, Silva e Gomes (2021), que tratam das dificuldades enfrentadas pela gestão escolar, de forma geral, e dos desafios futuros, por conta do retorno gradual às atividades presenciais. Estes autores acreditam que estão presentes desafios de diferentes ordens, relacionadas diretamente à complexidade de atribuições e de dimensões da gestão escolar em si.

Inicialmente, para estes autores, parecem prevalecer dificuldades relacionadas ao desenvolvimento pleno dos estudantes, ou seja, aquelas relacionadas aos processos de ensino e de aprendizagem na escola. Da mesma forma, as dificuldades podem se referir à reorganização curricular, no sentido de reestruturação de conteúdos e práticas, considerando os objetivos que 
não foram atingidos e aqueles que precisam ser, tanto do ponto de vista do grupo, quanto de cada estudante, elementos que também foram apontados pelos gestores, participantes desta pesquisa.

Ainda para Silva, Silva e Gomes (2021), os elementos da Gestão Administrativa são importantes para serem considerados neste período pandêmico, sobretudo os relacionados ao (re)planejamento e (re)organização escolar, evasão, inadimplência e concorrência (saúde financeira da escola). Lidar com perda de matrículas, manutenção de funcionários, práticas de formação continuada na escola e aumento no investimento em tecnologia tornaram-se uma problemática a ser equacionada pela gestão, o que levou alguns gestores, participantes deste estudo, a mencionarem-na como uma dimensão da gestão escolar bastante delicada neste período pandêmico.

Por fim, os estudos de Silva, Silva e Gomes (2021), apontam que há uma dificuldade relacionada ao estresse emocional e laboral de equipes e ao estresse emocional de estudantes, diretamente relacionados à uma possível fragilidade nas relações. Isso exige, para eles, um empenho por parte da gestão escolar em estruturar e fortalecer a dimensão de Gestão de Pessoas no contexto da escola, o que foi exaustivamente mencionado pelos participantes deste estudo como um dos principais desafios a serem enfrentados neste período e, consequentemente, uma das grandes oportunidades de sucesso e de transformação na escola.

\section{CONCLUSÃO}

Impactos e desafios se referem à gestão escolar como um todo, em suas dimensões e no contexto vivido da pandemia, pode-se dizer que os desafios vieram com mais intensidade, com uma situação nunca antes vivida por ninguém, que afetou todos os campos sociais.

Pesquisar neste contexto é um desafio, a começar pela baixa adesão a pesquisa de 30 para 6 , em escolas com disparidades entre número de alunos, professores e funcionários. O número baixo também se deve ao fechamento de muitas escolas no segmento privado na cidade pesquisada, o que pode justificar o não aceite à participação.

Os resultados demonstraram que os gestores são experientes na profissão e possuem formação acadêmica e continuada compatível com a função que exercem. Ainda que exista diferença quanto ao tamanho das escolas, em função da quantidade de alunos e dos funcionários, há uma proporção entre elas.

Em relação à concepção de Gestão Escolar, os participantes demonstraram reconhecer a importância de se exercer uma gestão democrática, embora tenham mencionado que algumas decisões competem, exclusivamente, ao Gestor Escolar.

Quanto às dimensões da gestão, os gestores participantes demonstraram ter mais facilidade com a Gestão Administrativa, Gestão de Pessoas e Gestão Pedagógica, quando as dimensões menos afins foram elencadas como sendo: a Gestão de Resultados Acadêmicos, sobretudo na pandemia, por não acompanhar de perto a evolução dos índices de aprendizagem no âmbito pedagógico.

Diante do cenário ocasionado pela pandemia do Covid-19, os participantes relataram que perceberam desafios e oportunidades. Os desafios estão relacionados às dificuldades de Gestão Financeira e Administrativa e as oportunidades em fortalecer a Gestão Pedagógica e de Pessoas, por meio da inclusão tecnológica e do desenvolvimento de uma comunidade de aprendizagem, permeada pela empatia entre escola e família. 
Estes resultados são consoantes à revisão de literatura realizada, por mostrar que houve dificuldades nos mais diversos âmbitos das dimensões, podendo constatar, por meio de profissionais da área a realidade teórica discutida e estudada.

Por fim, este estudo demonstra a necessidade de se realizar pesquisas desta natureza com um maior número de escolas e com escolas públicas, a fim de investigar o contexto da gestão escolar de forma mais abrangente em diferentes contextos, tempos e espaços de atuação.

\section{REFERÊNCIAS}

ALVES, S. M. C.; BARBOSA, M. R. B. Gestão escolar democrática: dimensão diretiva aos processos educacionais significativos Research, Society and Development, v. 9, n. 4, p.1-16, 2020.

ANDRADE, G. P. S. B.; BARBOSA, L. A.; CARDOSO, M. S.; OLIVIERA, R. M. S. R. Desafios para a construção de práticas docentes em tempo de pandemia. Research, Society and Development, $v$. 10, n. 1, p.1-11, 2021.

ARRUDA, E. P. Educação remota emergencial: elementos para políticas públicas na educação brasileira em tempos de Covid-19. EmRede - Revista de Educação a Distância, v. 7, n. 1, p. 257 275, 15 maio 2020.

BALDIN, A. M. A.; PEDERSETTU, S.; SILVA, M. B. Educação básica em tempos de pandemia: tentativas para minimizar o impacto do distanciamento e manter o vínculo entre os alunos, as famílias e a escola. 2020. In: PALÚ, J.; SHUTZ, J. A.; MAYER, L. (orgs.). Desafios da educação em tempos de pandemia. Cruz Alta: Ilustração, 2020.

BORGES, K. R.; FIGUEIREDO, S. T.; AVELINO, W. F. Gestores pedagógicos em escolas de ensino integral no estado de São Paulo durante a Pandemia da Covid-19. Boletim de Conjuntura (BOCA), Boa Vista, v. 5, n. 13, p. 69-76, 2021.

COUTO, E. S.; COUTO, E. S.; CRUZ, I. de M. P. \#Fiqueemcasa: Educação na pandemia da Covid-19. Revista Educação e Interfaces Científicas, v. 8, n. 3, p. 200-217, 2020.

CRESWELL, J. W. Projeto de pesquisa: métodos qualitativo, quantitativo e misto. 2. ed. Porto Alegre: Artmed, 2010.

DIODATO, J. R.; LIMA, J. C. S.; SILVA, A. P.; ANDRADE, L. C.; TEMUDO, S. P. Implicações da gestão democrática na construção do projeto político pedagógico e os reflexos da pandemia. VII Congresso Internacional das Licenciaturas, dez. 2021. Disponível em: <https://cointer.institutoidv.org/smart/2020/pdvl/uploads/1724.pdf>. Acesso em: 10 mar. 2021.

FERRAZ, J. P. V.; ABREU, D. C. DE; MOTTA, M. A. Regulação do trabalho pedagógico e escolar em tempo de pandemia. Notandum, n. 56, p. 111-121, 24 fev. 2021.

FIRMINO, M. A. R. Os desafios do gestor escolar em tempos de aprendizagem remota. Pedagogia em Ação, Belo Horizonte, v. 13, n. 1, p.275-278, 2020. 
FRANCO, L. R.; FRANCO, L. S. Educação Especial: reflexões sobre inclusão do estudante com deficiência em tempos de pandemia. 2020. In: PALÚ, J.; SHUTZ, J. A.; MAYER, L. (orgs.). Desafios da educação em tempos de pandemia. Cruz Alta: Ilustração, 2020.

GABRIEL, N. S.; MARÇAL, G. A.; IMBERNON, R. A. L.; PIOKER-HARA, F. C. O retorno às aulas no póspandemia: estudo de caso e análise comparativa entre o ensino público e o ensino privado. Terra e Didática, Campinas/SP, v. 17, n.1, p.1-13,2021.

GATTI, B; et. al. Professores do Brasil: novos cenários de formação. Brasília: UNESCO, 2019.

GIORDANO, D. X. F. Um olhar sobre o trabalho dos gestores escolares no contexto da pandemia. Educação Básica Online, v.1, n.1, p. 125-133, jan. 2021.

KIRCHNER, E. A. Vivenciando os desafios da educação em tempos de pandemia. In: PALÚ, J.; SHUTZ, J. A.; MAYER, L. (orgs.). Desafios da educação em tempos de pandemia. Cruz Alta: Ilustração, 2020.

LIBÂNEO, J. C. Organização e Gestão da Escola: teoria e prática. 6. ed. São Paulo: Heccus Editora, 2017.

LÜCK, H. Dimensões de gestão escolar e suas competências. Curitiba: Editora Positivo, 2009.

LÜCK, H. Concepções e processos democráticos de gestão educacional. 9. ed. Petrópolis, RJ: Vozes, 2013.

MARCONI, M. A.; LAKATOS, E. M. Fundamentos da metodologia científica. 8 ed. São Paulo: Atlas, 2017.

OLIVEIRA, V. C.; NEVES, O. L; MARTINS, R. N.; SANTOS, I. De repente 4.0: mudanças de paradigma educacional em tempo de pandemia. 2020. In: PALÚ, J.; SHUTZ, J. A.; MAYER, L. (orgs.). Desafios da educação em tempos de pandemia. Cruz Alta: Ilustração, 2020.

PALÚ, J.; SHUTZ, J. A.; MAYER, L. Desafios da educação em tempos de pandemia. Cruz Alta: Ilustração, 2020.

PERES, M. R. Novos desafios da gestão escolar e de sala de aula em tempos de pandemia. Revista Administração Educacional da UFPE, Recife-PE, v.11 n. 1 p. 20-31, jan./jun. 2020.

PRALON, E. A pandemia com reflexo no clima das instituições educacionais: instabilidade e o acentuado índice de incivilidades nas relações. Cadernos de Educação: Reflexões e Debates, v. 19, n. 38, p. 5-17, 2020.

REIS, J. S.; LEAL, D. A. A importância da democratização digital e seus reflexos na educação mediante a pandemia do COVID-19. Brazilian Journal of Development, Curitiba, v.7, n.1, p.1037110380, jan. 2021. 
RIBEIRO, G. S.; ANDRADE JOSÉ, M. C. Gestão escolar e a Covid-19: dinâmicas de trabalho e desafios profissionais durante a pandemia de 2020. In: SILVA, A. J. N.; BOMFIM, A. L. (orgs.). Militância política e teórico-científica da educação no Brasil. Ponta Grossa/PR: Atena, 2020.

SILVA, G.; SILVA, A. V.; GOMES, E. P. S. A gestão escolar em tempos de pandemia na capital alagoana. Jornal de Políticas Educacionais, v. 15, n. 1, jan. 2021.

SILVA, J. A. D.; WEINMAN, C. Os desafios de uma gestão democrática em tempos de pandemia na escola pública. 2020. In: PALÚ, J.; SHUTZ, J. A.; MAYER, L. (orgs.). Desafios da educação em tempos de pandemia. Cruz Alta: Ilustração, 2020.

THIOLLENT, M. Pesquisa-ação nas organizações. 2.ed. São Paulo: Atlas, 2009.

VALLE, P. D.; MARCOM, J. L. R. Desafios da prática pedagógica e as competências para ensinar em tempos de pandemia. 2020. In: PALÚ, J.; SHUTZ, J. A.; MAYER, L. (Org.). Desafios da educação em tempos de pandemia. Cruz Alta: Ilustração, 2020. 